\section{The influences of the downsizing strategy on business structures}

\section{Carmen Soria Bravo \\ Alfonso Herrero de Egaña}

UNED - Department of Applied Economics and Statistics, Madrid, Spain

\section{Abstract}

Purpose - This paper investigates the effectiveness of the downsizing strategy when applied to the Telefónica case.

Design/methodology/approach - By using the Event Study method, we present the relationship between downsizing strategies and results. Statistical significance of results was analyzed using t-statistics analysis.

Findings - Results are significant, proving that the downsizing strategy brought about greater profitability and better funding, leveraging company market values.

Originality/value - Results indicate that downsizing is a strategy alternative that allows for better adaptation, if carried out proactively and associated to changes that are necessary within organizational structure and processes.

Keywords - Downsizing; event study; strategy; Telefónica.
Received on

$02 / 22 / 2016$

Approved on

$10 / 11 / 2016$

Responsible editor:

PhD. J. Ignacio Canales

\section{Evaluation process: \\ Double Blind Review}

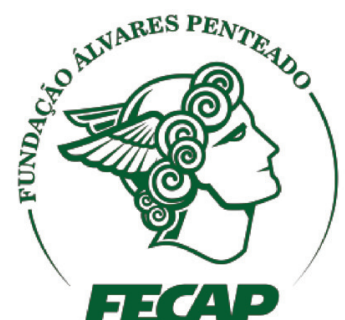

Review of Business Management 


\section{Introduction}

From the 1990 s to the present day, a considerable number of companies have reduced the size of their businesses and restructured their core competencies, aiming at achieving greater flexibility and profits. The Population Ecology Theory (Hannan \& Freeman, 1984) states that the best corporate practices tend to be copied, thereby standardizing entrepreneurial structures and strategies. As such, the best organizational structure is that which best manages to adapt to surroundings and continues to operate in an efficient way (Porter, 1985), both in its economic and financial results as well as in social and environmental aspects.

Thus, this strategy is copied en masse, both in the industrial and services sectors (Littler, 1998; Gandolfi, 2007) in the USA, Europe, Asia and specifically in Spain (Morris, Cascio, \& Young, 1999; Suarez Gonzalez, 2000; Dahl and Neshheim, 1998); in many cases, however, it is implemented in a partial way, without achieving the required organizational changes, thus failing to obtain the desired results (Magán \& Céspedes, 2012).

\section{Downsizing as a strategic alternative}

The term downsizing was first used referring to strategies to reduce personnel; however, to the extent that it has become more and more relevant, its scope has been expanded and now refers to a wide range of management measures geared towards better adapting an organization to its environment (Gandolfi \& Hansson, 2011). In this sense, reductions in personnel are intended to achieve cost effectiveness, while the broader term strives for a transformation aimed at changing the design of the organization, as well as its processes, culture and values.

The evolution of the term itself means there is no single definition of downsizing accepted by all researchers (Davis, Savage,
Steward, \& Chapman, 2003). In this study, we use the term in a broad sense, as a systemic change, defining downsizing as a strategic alternative which includes different combinations of reductions in a company's physical, human and organizational systems, to adapt it to the competitive conditions of a business unit (Dewitt, 1998).

The intention, the time and the effects on work and personnel processes are the key characteristics of the term downsizing. As such, the selection of the limited resources available to the company, and the latter's adaptation to the environment, will result in its survival. These characteristics also set this strategy apart from other associated terms, such as decline, in which there is no intention; lack of adaptation, given that downsizing prevents it; decrease, since this also occurs during periods of growth; or layoffs, which do not always occur and may be a consequence of the strategy, but not the strategy in itself.

The presented downsizing model features three strategies within a range of possibilities between remaining within or leaving industry. This classification is also used in research conducted by Greenhalgh, Lawrence, and Sutton (1998), and by Budros (2002).

- Retrenchment or expense reduction: a strategy based on improving productivity by bringing together production plants and eliminating superfluous work (Freeman \& Cameron, 1993).

- Downscaling or scale reduction: maintains the field of activity while trimming a company's human and physical resources, reducing output in order to adapt to demand (Kotler, 1986; Whitney, 1996).

- Downscoping, Refocusing or restructuring of corporate portfolios (Johnson, 1996; Markides, 1995; Kreiken, 1980): involves reducing the field of activity by lowering the vertical and horizontal differentiation of the value chain. 


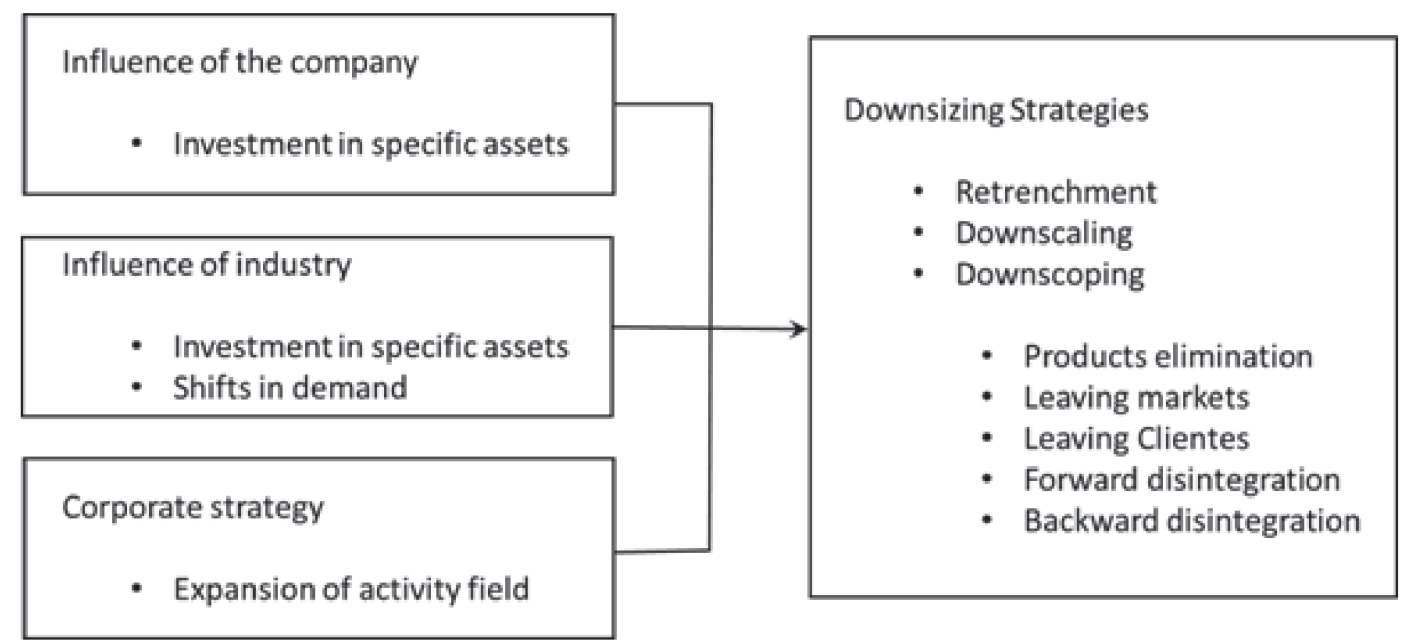

Figure 1. Downsizing strategies according to reduced resources Source: Adapted from Dewitt (1998)

Selecting a specific downsizing strategy depends on three factors: the company's resources, its investments and its field of activity. The company's resources at a given time may provide competitive advantages, but also reduce possibilities with regard to mobility and to leaving the sector. Thus, a downsizing strategy will be satisfactory provided the value generated by the resources when sold on the market is greater than the organization would obtain by keeping them. Secondly, the most recent investments the company has made in capacity or products will ensure greater income (Caves \& Porter, 1976), but limit the strategy's reduction scope, thus focus on a reduction in costs becoming more likely than a reduction in scale or scope. In parallel, lack of investments or a reduction in demand in the industry increase the likelihood of reducing scale or scope.

Depending on the specific objectives pursued, one of the strategies for reducing resources is selected (Gresov, 1989). Thus, retrenchment is more likely when the company has not invested in capacity or products and is striving to take advantage of capacity, or when the company's competitors have been making investments. Downscaling involves closing down large plants, and as such is carried out when the company operates in a broad field of activity and has not been making investments, or in the event of a drop in demand. Finally, downscoping involves closing down units to reduce the variety of what is produced - and this is why this strategy is more effective in a broad field and without investments in capacity but rather in products.

Company managers face pressure from shareholders to improve financial results; many managers believe that layoff strategies reveal clear and predictable information, however layoffs in themselves cannot be said to improve financial results in the long term (Muñoz, F. \& Sanchez, M., 2010). If the downsizing strategy is implemented in an inadequate manner, the results will not be achieved, and something more is required than simple layoffs as a means of renovating an organization and repositioning it within the market. Hence the importance of implementing the strategy. In this sense, the idea of adaptation has been a key factor in the success of organizations (Nadler \& Tushman, 1988).

In line with the systemic approach, organizational adaptation occurs when organizational design is aligned with the series of contextual factors and internal variables dealt with by the organization. As illustrated in the Nadler and Tushman model, the organization's efficacy is the result of the adaptation of its components. 


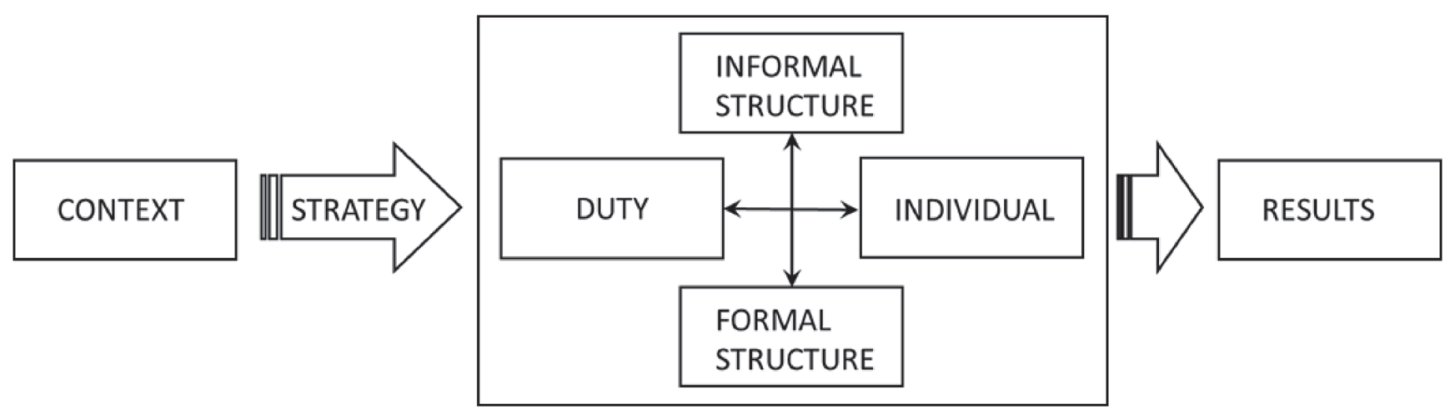

Figure 2. Organizational diagram

Fonte: Adapted from Nadler and Tushman (1998)

One of the key components is context, which refers to the company's environment, competition, demand, resources and capacities, in addition to its history.

In other words, it encompasses the conditions of the environment in which the organization conducts its activities. The company's strategy defines the series of decisions made by the senior management with regard to its association with the environment, that is to say, on what bases it competes and how it strives to achieve its objectives. In second place comes structure, a fundamental aspect in relation to implementation, involving the means to ensure the said strategy is effective. And, finally, the results indicate the degree of efficacy and efficiency with regard to achieving the predefined objectives.

The central idea of this model is that an organization's efficacy will depend on the level of adaptation between the different components. From the viewpoint of corporate management, structural variables highlight the importance of formal organizational variables, on which management can act to correct imbalances in the long term. As such, the study focuses on the adaptation between the company's strategy and its formal structure. In this sense, Sutton and D'Aunno (1989) illustrate two structural shifts:

- Long-term shifts towards mechanical structures: more centralized and standardized
- Shifts towards organic structures, where the expertise of personnel and interdependencies are mechanisms of coordination and control.

Hence, the implementation of downsizing strategies will alter, where necessary, the company's structural design, changing the structures, processes and methods created to help individuals perform their duties, allowing for the correct implementation of downsizing (Worley \& Lawler, 2006). The type of structural shift will depend on the downsizing strategy selected and the organization's existing structure, in striving to adapt to the change in the environment and to reassigning human resources to the activities to be carried out.

\section{Analysis model}

The model should analyze the downsizing strategy according to the company's specific and sectoral characteristics, and subsequently ascertain whether or not the structural shifts associated with the different strategies geared to achieving the company's objectives of efficacy, competitiveness and productivity have occurred. In other words, it should ascertain whether or not the appropriate relationship between the downsizing strategy and the company's structure leads to improved results. 


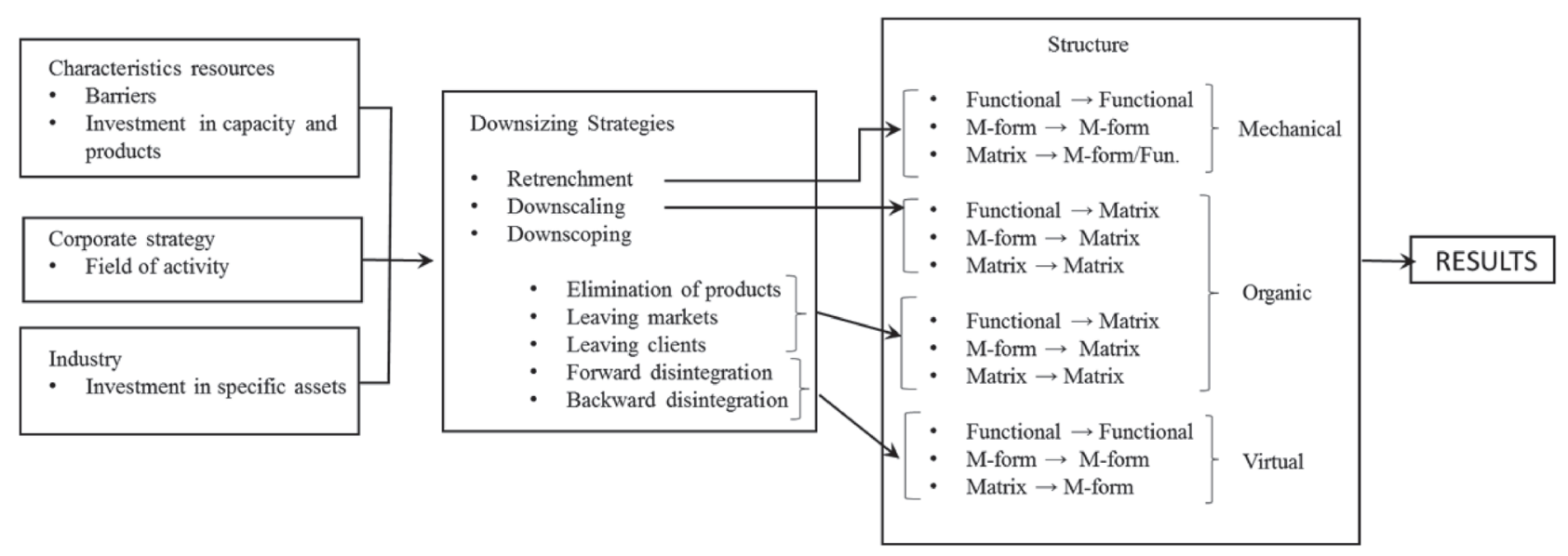

Figure 3. Analysis model

Retrenchment strategy involves specialized production, concentrating activities until economies of scale have been achieved. In this sense, the structures will lean towards mechanical models, with increased levels of standardization, formalization and centralization.

The downscaling strategy is associated with structural shifts geared towards organic configurations, reducing levels of horizontal differentiation and standardization and increasing levels of vertical differentiation and centralization.

Downscoping strategies involve reducing the level of complexity of the product-market binomial, resulting in a smaller differentiation of activities in the value chain. By reducing the complexity of the organization, the primary structure will tend to remain in place, but the differentiation in activities and standardization will be reduced, resulting in shifts towards virtual structures or corporate chains. These virtual structures combine the normative nature, which provides answers referring to the organization's internal design, and the ecological nature, which maintains or changes the organization according to its needs over time.

The empirical study conducted focuses on downscoping strategies, since, according to corporate evidence, most diversified companies have reduced their levels of diversification since the 1990s, and, as such, this is the most common strategy.
For this analysis, a case study is carried out - which, as demonstrated in various studies, and when one or more organizations are being analyzed, allows for examining a current phenomenon in its own context. Furthermore, this is particularly relevant in fields of investigation featuring complex processes in which different variables interrelate. Case studies have also been used to analyze downsizing as a fact within an organization's life, not only as a pre-post photo of the implementation of downsizing (Chinzer \& Currie, 2014).

The results of the case study were complemented by valuation conducted by stock market analysts, using stock measures. In third place, analysis of results requires us to ascertain whether or not the implemented downsizing strategies had an effect on the same; to this end, an event study is carried out. Hotchkiss and Stricklan (2003) use this methodology to analyze how investors react to information events.

Within the event study, we must analyze how financial markets react both to the event and to information about it; this is why we must create event windows in which to analyze the effect of the company's profitability. The date of the event is the time at which the information provided by the company brings about effects, or the dates around which the event brings about effects. This research, by referring to downscoping strategies, takes into account a temporal window of four 
months prior to the official sale of the business, and four months after the same. The relevant facts disclosed by the company are the basis for calculating these temporal windows, since they include all information the knowledge of which might reasonably affect an investor acquiring or transferring assets.

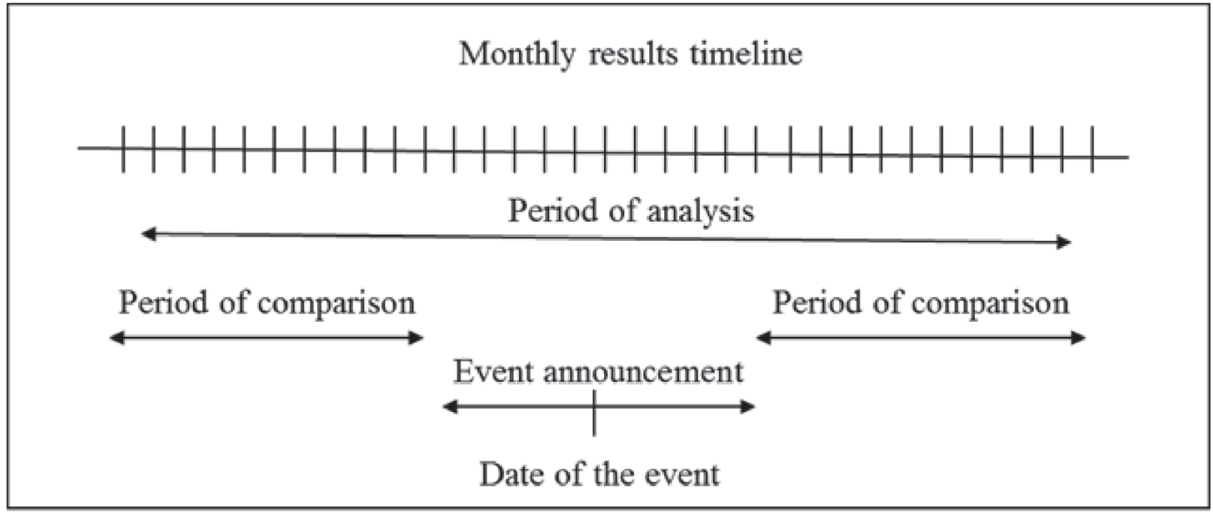

Figure 4. Definition of the analysis period in an event study

Source: Johnson, K.H. (1998)

A sector which was going through a phase of growth at the same time as the downsizing strategies were implemented was selected for this study, as a means of analyzing these corporate reduction strategies apart from the decline effect. As such, this empirical study was conducted in the telecommunications sector, a sector undergoing expansion and, moreover, one in which major importance is placed on investment in specific assets, shifts in demand and the amplitude of the field of activity - all factors defined as important in selecting a downsizing strategy.

\section{Empirical analysis, the Telefónica S.A. case}

The telecommunications sector underwent a structural change due to the deregulation processes implemented from the 1990s on; the latter led companies to analyze the business they were involved in, joining or leaving the different lines of business in a process consisting of searching for and selecting fields of activity. Most telecommunications companies used to be public and held a monopoly in their local markets.

According to research by López (2002), globalization changes trade patterns, increasing the internationalization of companies, enabling the exploitation of technological and organizational advantages on a global scale, in addition to reducing costs, joining new markets and diversifying investment risks. Within this global market, Telefónica has continuously changed its business, progressing from its beginning as a local company with a monopoly to a multinational company operating in four continents with high levels of operating efficiency.

As of the late 1980s, the liberalization of the sector in almost every country, as well as the removal of barriers to the entry of foreign capital, have generated opportunities for internationalization, which Telefónica was able to take advantage of by acquiring companies which were already established in other countries. This was the period in which the Telefónica group underwent considerable growth by geographic areas, beginning from Latin America, the nucleus of its expansion, and Eastern Europe (Telefónica, 2006).

The new perspective of an integrated multinational corporation was reflected in cost savings, by allowing synergies to be reached due to the promotion of common products and 
services, the rationalization of networks, brand recognition, the transfer of knowledge within the group and economies of scale - through which global products, suppliers and technological standards provided Telefónica with greater negotiating power (Telefónica, 1985-2006).

The quest for efficiency also led the company to gradually separate resources and activities which were not part of the core business. Hence, the Joint Services Centers were created as units shared among different lines of business to manage management activities, providing their services in market conditions. These internal units enabled the company to obtain more economies of scale and to render business more flexible by moving from fixed costs to variable costs according to the volume to be managed, to concentrate the resources of each unit in its main activity, and to prevent staff units from multiplying.

Other divestments conducted at this time clearly involved downscoping strategies, implemented through gradual dismissal of nonstrategic holding in businesses which were not key to the group's activity, such as telephone booths, data transmission and the installation of telephone equipment and lines.

In light of this new scenario, Telefónica based its development over the next three years on three sources of growth:

- Strengthening strategic partnerships which were not key to the group

- Continuing expansion in Latin America

- Promoting developing businesses by means of agreements and acquisitions. A noteworthy example is the media business geared to maximizing the value of Telefónica distribution networks and reinforcing the capacity to create and exploit content. Over the 2000-2003 period, Telefónica Media conducted a series of agreements and acquisitions, the highlights of which were the acquisition of Endemol, Vía Digital and Antena 3 Televisión in Spain, and of Telefé and Canal Azul in Argentina.
As of 2003, Telefónica focused its strategic priorities on strengthening its position in key markets and on improving operating efficiency, continuing the cost and investment control policy by disposing of businesses which had failed to live up to expectations. Thus, the Telefónica Media business, which boomed since 2000, underwent processes involving divestments and the realignment of investments as of 2003, since, due to its size, Telefónica was able to successfully negotiate its broadband content with all producers without being associated with any one of them in particular. This downscoping strategy culminated in the selling of Endemol in 2007. Meanwhile, the group implemented processes involving the realignment of investments in non-strategic assets, such as Airwave - specializing in digital security communications - and TPI - specializing in the telephone directory market.

Parallel to these divestment processes, Telefónica has been concentrating its activities in the telecommunications business since 2005, expanding it to the fields of Added Value Services and digital content. Key businesses are conducted by geographic area, one of the highlights of which was the acquisition of all the shares of O2, 50\% of Colombia de Telecomunicaciones S.A., later named Telefónica Telecom, an increased stake in Telecom Italia, and joining and increasing its holding in the China Netcom Group.

Moreover, Telefónica modified its structure over the years in order to adapt to the defined strategy, according to the following phases:

- In 1994, a structure according to lines of business with a focus on markets, clients and products was approved. In turn, the corporate center directs the group's strategy and conducts activities involving management planning and control, corporate finances and institutional relations. Finally, two joint resources units - infrastructure and resources - provide support to business units.

- New lines of business were created in 1999 to take advantage of business 
opportunities by geographic areas or lines of activity, and greater importance was placed on audiovisual and multimedia businesses and on the development of the Internet.

- The structure according to lines of business was maintained in the following years, pursuant to the initial development of the different units and the subsequent restructuring of the same.

- In 2006, the time at which the Group restructured its activities with a focus on the key business, Telefónica adopted a regional and integrated management model, creating three general departments in charge of all the fixed and mobile assets in Spain, Europe and Latin America.

This systemic change in the structure with the strategy enabled the Group to find an appropriate combination in relation to both scale and the diversification of business by activity and geographic area, allowing it to take advantage of growth in the different lines of business and to extract value from scale and diversity by means of integrated management. As such, the greater integration of Telefónica's businesses enabled the organization to carry out global infrastructure and systems projects and to centralize activities such as purchases and the commercial convergence of products, services and channels.

In addition, the system of regional management enabled the company to place a greater focus on customers, ensuring the development of products and services was conducted in a dynamic manner, and at the rate defined by the different markets. This focus on customers led to structural shifts towards organic configurations, placing importance on knowledge of the organization as a whole, lateral rather than vertical communication and communication based on information and advice rather than instructions and decisions.
Improved levels of operating efficiency enabled the company to act according to the requirements of the current competitive environment, reducing investments gradually. In this sense, both the efforts made in relation to IT and the reductions in personnel in consolidated business, particularly the landline telephone business, were of paramount importance.

It should be stressed that the aim of the employment regulation plan proposed by the company was to guarantee the competitiveness of consolidated business in the new market environment, based on the principles of voluntariness, universality and non-discrimination of employees with regard to layoffs, using procedures involving the functional and geographic redeployment of the workforce still associated with the company, as well as specific training plans to provide cover for the new professional profiles demanded by the environment.

All these shifts indicate that the downsizing processes have been implemented in a systemic manner, enabling the company to grow in terms of resources, at the same time as reducing the size of the different units to render them more flexible and to adapt them to the environment.

With regard to the results obtained, we should conduct a long-term analysis in order to ascertain the advantages obtained from the definition and implementation of the strategies (Hyderabad, 2014). In this sense, shareholder profitability in the 16 years under analysis registered an annual average of $19.1 \%$, higher than that of IBEX 35 (Fernández \& Carabias, 2007). In relation to the profitability of the biggest companies listed on the stock market, Telefónica ranked third in the period 2003-2007, and rose from twelfth to second place in 2008 in relation to capitalization. 
Table 1

Evolution of profitability, Telefónica, $1992-2007$

\begin{tabular}{|l|c|c|c|c|c|c|c|c|c|}
\hline & $\mathbf{1 9 9 2}$ & $\mathbf{1 9 9 3}$ & $\mathbf{1 9 9 4}$ & $\mathbf{1 9 9 5}$ & $\mathbf{1 9 9 6}$ & $\mathbf{1 9 9 7}$ & $\mathbf{1 9 9 8}$ & $\mathbf{1 9 9 9}$ & \\
\hline Profitability (mil. euro) & $2.5 \%$ & $9.2 \%$ & $13.7 \%$ & $1.3 \%$ & $4.4 \%$ & $6.8 \%$ & $3.9 \%$ & $04.4 \%$ & \\
\hline & $\mathbf{2 0 0 0}$ & $\mathbf{2 0 0 1}$ & $\mathbf{2 0 0 2}$ & $\mathbf{2 0 0 3}$ & $\mathbf{2 0 0 4}$ & $\mathbf{2 0 0 5}$ & $\mathbf{2 0 0 6}$ & $\mathbf{2 0 0 7}$ & \\
\hline Profitability (mil. euro) & $-29.0 \%$ & $-11.1 \%$ & $-41.0 \%$ & $46.6 \%$ & $22.7 \%$ & $-1.2 \%$ & $31.2 \%$ & $41.7 \%$ & $19.1 \%$ \\
\hline
\end{tabular}

Table 2

Comparison between the profitability of telecommunications companies

\begin{tabular}{|c|c|c|c|c|c|c|c|c|c|c|}
\hline & 1998 & 1999 & 2000 & 2001 & 2002 & 2003 & 2004 & 2005 & 2006 & 2007 \\
\hline $\begin{array}{l}\text { China Mobile } \\
\text { Hong Kong }\end{array}$ & 20.377 & 85.691 & 101.615 & 65.495 & 46.793 & 60.432 & 66.786 & 93.802 & 172.303 & 354.154 \\
\hline AT\&T Inc & 104.891 & 166.305 & 161.632 & 131.672 & 90.011 & 86.309 & 85.438 & 96.601 & 137.384 & 252.051 \\
\hline $\begin{array}{l}\text { Vodafone Group } \\
\text { Plc }\end{array}$ & 50.238 & 153.784 & 236.831 & 178.181 & 124.283 & 169.737 & 177.746 & 132.757 & 146.132 & 198.564 \\
\hline Telefónica SA & 46.555 & 81.118 & 71.725 & 62.524 & 43.507 & 72.762 & 93.361 & 73.780 & 104.605 & 154.730 \\
\hline $\begin{array}{l}\text { Verizon } \\
\text { comunications } \\
\text { Inc }\end{array}$ & 83.823 & 95.593 & 135.292 & 129.839 & 106.011 & 96.875 & 112.170 & 83.281 & 108.723 & 126.278 \\
\hline $\begin{array}{l}\text { Deutsche } \\
\text { Telekom AG }\end{array}$ & 90.275 & 214.371 & 91.304 & 72.512 & 53.827 & 76.986 & 94.940 & 70.661 & 81.026 & 95.622 \\
\hline France Telecom & 81.422 & 134.865 & 99.606 & 46.130 & 20.867 & 68.663 & 81.686 & 64.397 & 71.910 & 93.698 \\
\hline NTT (XSQ) & 119.839 & 267.099 & 112.315 & 51.591 & 57.912 & 77.301 & 74.278 & 80.112 & 77.616 & 77.016 \\
\hline $\begin{array}{l}\text { NTT Docomo } \\
\text { Inc }\end{array}$ & 78.945 & 367.677 & 165.190 & 117.926 & 92.605 & 113.779 & 92.554 & 74.269 & 73.856 & 74.758 \\
\hline $\begin{array}{l}\text { American Movile } \\
\text { SA DE CV }\end{array}$ & - & - & - & 9.525 & 6.346 & 11.994 & 22.204 & 35.822 & 54.667 & 69.476 \\
\hline Telecom Italia & 9.837 & 13.608 & 11.740 & 9.344 & 9.022 & 30.537 & 42.202 & 38.798 & 40.405 & 41.480 \\
\hline $\begin{array}{l}\text { Sprint Nextel } \\
\text { Corp }\end{array}$ & 60.215 & 69.710 & 45.920 & 35.829 & 31.951 & 46.640 & 49.431 & 37.023 & 33.431 & 42.666 \\
\hline WorldCom (3) & 131.548 & 150.609 & 40.487 & 41.668 & 409 & 39 & - & - & - & - \\
\hline Bellsouth (1) & 97.535 & 88.116 & 76.408 & 71.606 & 48.081 & 52.302 & 50.905 & 49.556 & 85.932 & - \\
\hline $\begin{array}{l}\text { Telefónica } \\
\text { Moviles (2) }\end{array}$ & - & - & 39.488 & 31.008 & 28.174 & 45.228 & 54.505 & 45.310 & 60.873 & - \\
\hline $\begin{array}{l}\text { Telecom Italia } \\
\text { Mobile }\end{array}$ & 49.123 & 73.810 & 67.303 & 47.084 & 38.496 & 45.848 & 63.070 & 43.871 & 49.042 & - \\
\hline
\end{tabular}

Share prices vary according to the announcement of events, but we should analyze the results of these strategies in the long term as a means of ascertaining advantages obtained from them (Hyderabad, 2014). Accordingly, and to conclude this research, the event study included a specific analysis of four downsizing decisions made by Telefónica, specifically the disposal of Antena 3 TV, TPI, Airwave and Endemol, as illustrated in the table below. 


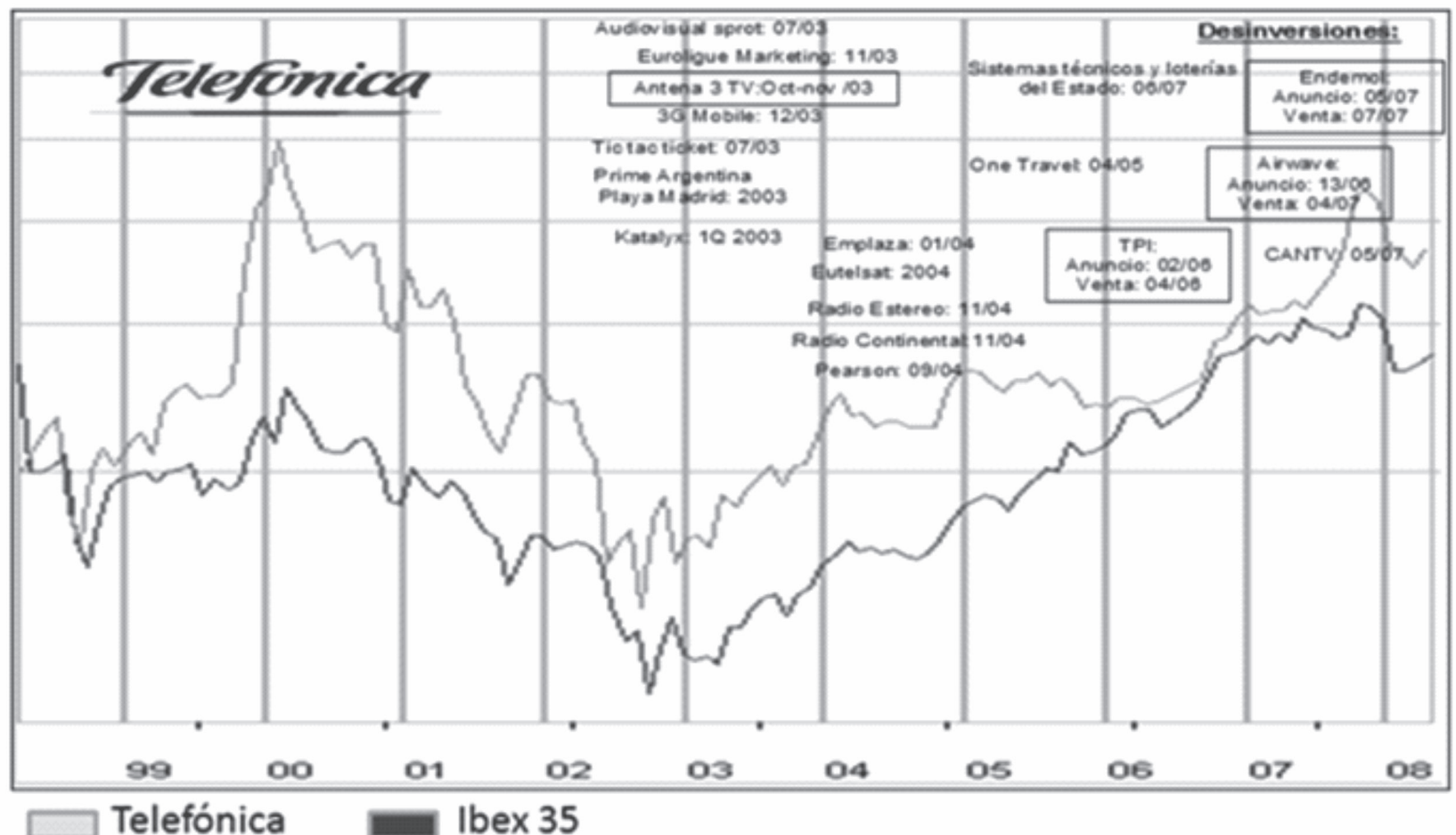

Figure 5. Disposals in the business under analysis

The data in this study was taken from stock market prices for Telefonica over the 2000-2007 period, years in which the downsizing strategies in question were implemented. Likewise, we obtained the prices of the indexes against which the events are to be analyzed. The markets selected were the Dow Jones Industrial Average efficient market, and the S\&P 500 index, which is normally used as a proxy for the market as a whole. The IBEX 35 index was eliminated, since the capitalization of Telefónica S.A. represents $15-20 \%$ of the total capitalization of the index, which would detract from the result.

By definition, a market itself has a beta, which represents its trend or slope. Individual companies participating in the markets are also classified according to their deviation in relation to the market in question. Once the temporal windows used in the study have been defined, the corresponding betas are calculated for Telefónica and each of the indexes, calculated outside the temporal window under analysis - based on the maximum and minimum closing prices in order to obtain a wide range of profitability -, and taking into account a period of time ten times greater than the temporal window. The company's forecast profitability for each temporal window is calculated and compared to the indexes, illustrating the variation in profitability due to the event analyzed.

$$
\mathrm{ER}=\mathrm{R}_{\mathrm{TEL}}-\beta \mathrm{R}_{\text {index }}
$$

The hypothesis that the excess profitability in the temporal window is different from zero is estimated using the T-student method, dividing the average variation in profitability in the temporal window by the standard error obtained in the same. The results of the statistical analysis are statistically significant and register extraordinary results associated with the months subsequent to the implementation of the downsizing strategy by the company, as illustrated in the tables below: 
Table 3

Results of the event study analysis in relation to Dow Jones

\begin{tabular}{|c|c|c|c|c|c|c|c|c|c|}
\hline \multicolumn{3}{|c|}{ ANTENA 3 TV (JUL 03 - MAR 04) } & Beta : & 0,9576 & \multicolumn{5}{|c|}{ DJI } \\
\hline & \multicolumn{4}{|c|}{ ANNOUNC. } & SELL & \multicolumn{4}{|c|}{ POST } \\
\hline & jul-03 & ago-03 & sep-03 & oct-03 & nov-03 & dic- 03 & ene-04 & feb-04 & mar-04 \\
\hline Media & 0.0271 & -0.0237 & -0.0102 & -0.0022 & 0.0219 & 0.0623 & 0.0425 & -0.0156 & 0.0102 \\
\hline St. Dev. & 0.0622 & 0.0684 & 0.0675 & 0.0532 & 0.0612 & 0.0783 & 0.0672 & 0.0649 & 0.0651 \\
\hline \multirow[t]{2}{*}{ T-STUDENT } & 3.9147 & -3.1219 & -1.3581 & -0.3660 & 3.2225 & 7.1603 & 5.6935 & -2.1673 & -1.4157 \\
\hline & 1.99 & 1.99 & 1.99 & 1.99 & 1.99 & 1.99 & 1.99 & 1.99 & 1.99 \\
\hline \multicolumn{2}{|c|}{$\begin{array}{l}\text { RADIO ARGENTINA (JUL } 04 \\
\text { - MAR 05) }\end{array}$} & Beta : & \multicolumn{7}{|c|}{1,0027} \\
\hline & \multicolumn{4}{|c|}{ ANNOUNC. } & SELL & \multicolumn{4}{|c|}{ POST } \\
\hline & feb-07 & mar-07 & abr-07 & may-07 & jun-07 & jul-07 & ago-07 & sep-07 & oct-07 \\
\hline Media & 0.0081 & -0.0392 & -0.0106 & 0.0421 & 0.0119 & -0.0022 & -0.0152 & 0.0573 & 0.0454 \\
\hline St. Dev. & 0.0427 & 0.0358 & 0.0537 & 0.0583 & 0.0472 & 0.0452 & 0.0419 & 0.0707 & 0.0697 \\
\hline \multirow[t]{2}{*}{ T-STUDENT } & 1.7114 & -9.8672 & -1.7763 & 6.4908 & 2.2744 & -0.4443 & -3.2746 & 7.2923 & 5.8584 \\
\hline & 1.99 & 1.99 & 1.99 & 1.99 & 1.99 & 1.99 & 1.99 & 1.99 & 1.99 \\
\hline \multicolumn{2}{|c|}{ AIRWAE (ENE-SEPT 07) } & & Beta: & \multicolumn{6}{|c|}{0.9971} \\
\hline & \multicolumn{4}{|c|}{ ANNOUNC. } & SELL & \multicolumn{4}{|c|}{ POST } \\
\hline & ene-07 & feb-07 & mar-07 & abr-07 & may-07 & jun-07 & jul-07 & ago-07 & sep-07 \\
\hline Media & 0.0123 & -0.0279 & -0.0072 & -0.0398 & -0.0174 & 0.0369 & 0.0622 & 0.0359 & 0.1192 \\
\hline St. Dev. & 0.0459 & 0.0563 & 0.0582 & 0.0438 & 0.0402 & 0.0531 & 0.0667 & 0.0873 & 0.1264 \\
\hline \multirow[t]{2}{*}{ T-STUDENT } & 2.4095 & -4.4537 & -1.1164 & -8.1738 & -3.8886 & 6.2478 & 8.3898 & 3.7026 & 8.4868 \\
\hline & 1.99 & 1.99 & 1.99 & 1.99 & 1.99 & 1.99 & 1.99 & 1.99 & 1.99 \\
\hline \multicolumn{3}{|c|}{ ENDEMOL (FEB-OCT 07) } & Beta : & \multicolumn{6}{|c|}{1.0157} \\
\hline & \multicolumn{4}{|c|}{ ANNOUNC. } & SELL & \multicolumn{4}{|c|}{ POST } \\
\hline & feb-07 & mar-07 & abr-07 & may-07 & jun-07 & jul-07 & ago-07 & sep-07 & oct-07 \\
\hline Media & 0.0278 & -0.0081 & -0.0406 & -0.0175 & 0.0369 & 0.0626 & 0.0352 & 0.1189 & 0.1007 \\
\hline St. Dev. & 0.0566 & 0.0586 & 0.0444 & 0.0405 & 0.0535 & 0.0673 & 0.0878 & 0.126 & 0.1126 \\
\hline \multirow[t]{2}{*}{ T-STUDENT } & -4.420 & -1.2357 & -8.2359 & -3.8886 & 6.2099 & 8.3719 & 3.6087 & 8.4479 & 8.0480 \\
\hline & 1.99 & 1.99 & 1.99 & 1.99 & 1.99 & 1.99 & 1.99 & 1.99 & 1.99 \\
\hline
\end{tabular}


Table 4

Results of the event study analysis in relation to S\&P 500

\begin{tabular}{|c|c|c|c|c|c|c|c|c|c|}
\hline \multicolumn{3}{|c|}{ ANTENA 3 TV (JUL 03 - MAR 04) } & Beta : & 1.0949 & \multicolumn{5}{|c|}{ S\&P500 } \\
\hline & \multicolumn{4}{|c|}{ ANNOUNC. } & SELL & \multicolumn{4}{|c|}{ POST } \\
\hline & jul-03 & ago-03 & sep-03 & oct-03 & nov-03 & dic-03 & ene-04 & feb-04 & mar-04 \\
\hline Media & 0.0383 & -0.0201 & -0.0013 & -0.0153 & 0.0478 & 0.0455 & 0.0119 & -0.0496 & 0.0251 \\
\hline St. Dev. & 0.0628 & 0.0699 & 0.0691 & 0.0584 & 0.0615 & 0.0787 & 0.0740 & 0.0629 & 0.0657 \\
\hline \multirow[t]{2}{*}{ T-STUDENT } & 5.4858 & -2.5866 & -0.1648 & -2.3507 & 6.9971 & 5.2026 & 1.4461 & -7.1029 & 3.4361 \\
\hline & 1.99 & 1.99 & 1.99 & 1.99 & 1.99 & 1.99 & 1.99 & 1.99 & 1.99 \\
\hline \multicolumn{2}{|c|}{$\begin{array}{l}\text { RADIO ARGENTINA (JUL } 04 \text { - } \\
\text { MAR } 05\end{array}$} & Beta : & \multicolumn{7}{|c|}{1.00267} \\
\hline & \multicolumn{4}{|c|}{ ANNOUNC. } & SELL & \multicolumn{4}{|c|}{ POST } \\
\hline & jul-04 & ago-04 & sep-04 & oct-04 & nov-04 & dic- 04 & ene-05 & feb-05 & mar-05 \\
\hline Media & -0.0248 & 0.0245 & 0.0762 & -0.0021 & 0.0101 & 0.0172 & 0.0084 & -0.0238 & 0.0028 \\
\hline St. Dev. & 0.0499 & 0.0477 & 0.0506 & 0.0562 & 0.0498 & 0.0465 & 0.0456 & 0.0464 & 0.0460 \\
\hline \multirow[t]{2}{*}{ T-STUDENT } & -4.4729 & 4.6280 & 13.5413 & -0.3427 & 1.8293 & 3.3320 & 1.6581 & -4.6175 & 0.5493 \\
\hline & 1.99 & 1.99 & 1.99 & 1.99 & 1.99 & 1.99 & 1.99 & 1.99 & 1.99 \\
\hline \multicolumn{2}{|c|}{ TPI (FEB-OCT 06) } & & Beta : & \multicolumn{6}{|c|}{0.9769} \\
\hline & \multicolumn{4}{|c|}{ ANNOUNC. } & SELL & \multicolumn{4}{|c|}{ POST } \\
\hline & feb-07 & mar-07 & abr-07 & may-07 & jun-07 & jul-07 & ago-07 & sep-07 & oct-07 \\
\hline Media & 0.0233 & -0.0371 & -0.0202 & 0.0413 & 0.0274 & 0.0144 & -0.0081 & 0.0639 & 0.0298 \\
\hline St. Dev. & 0.0413 & 0.0335 & 0.0490 & 0.0561 & 0.0481 & 0.0471 & 0.0445 & 0.0704 & 0.0711 \\
\hline \multirow[t]{2}{*}{ T-STUDENT } & 5.0725 & -9.9666 & -3.7154 & 6.6223 & 5.1280 & 2.7471 & -1.6368 & 8.1669 & 3.7751 \\
\hline & 1.99 & 1.99 & 1.99 & 1.99 & 1.99 & 1.99 & 1.99 & 1.99 & 1.99 \\
\hline \multicolumn{3}{|c|}{ AIRWAE (ENE-SEPT 07) } & Beta : & \multicolumn{6}{|c|}{1.1246} \\
\hline & \multicolumn{4}{|c|}{ ANNOUNC. } & SELL & \multicolumn{4}{|c|}{ POST } \\
\hline & ene-07 & feb-07 & mar-07 & abr-07 & may-07 & jun-07 & jul-07 & ago-07 & sep-07 \\
\hline Media & -0.0240 & 0.0458 & -0.0418 & -0.0483 & 0.0384 & 0.0550 & 0.1006 & 0.0929 & 0.0337 \\
\hline St. Dev. & 0.0547 & 0.0577 & 0.0457 & 0.0468 & 0.0497 & 0.0624 & 0.0891 & 0.1326 & 0.1136 \\
\hline \multirow[t]{2}{*}{ T-STUDENT } & -3.9544 & 7.1404 & -8.2322 & -9.2912 & 6.9651 & 7.9333 & 10.1653 & 6.3061 & 2.6703 \\
\hline & 1.99 & 1.99 & 1.99 & 1.99 & 1.99 & 1.99 & 1.99 & 1.99 & 1.99 \\
\hline \multicolumn{3}{|c|}{ ENDEMOL (FEB-OCT 07) } & Beta : & \multicolumn{6}{|c|}{1.1397} \\
\hline & \multicolumn{4}{|c|}{ ANNOUNCEMENT } & SELL & \multicolumn{4}{|c|}{ POST } \\
\hline & feb-07 & mar-07 & abr-07 & may-07 & jun-07 & jul-07 & ago-07 & sep-07 & oct-07 \\
\hline Media & -0.0240 & 0.0459 & -0.0424 & -0.0489 & 0.0385 & 0.0552 & 0.1010 & 0.0924 & 0.0333 \\
\hline St. Dev. & 0.0549 & 0.0580 & 0.0461 & 0.0472 & 0.0499 & 0.0627 & 0.0896 & 0.1330 & 0.1138 \\
\hline \multirow[t]{2}{*}{ T-STUDENT } & -3.9261 & 7.1232 & -8.2746 & -9.3190 & 6.9464 & 7.9203 & 10.1512 & 6.2512 & 2.6345 \\
\hline & 1.99 & 1.99 & 1.99 & 1.99 & 1.99 & 1.99 & 1.99 & 1.99 & 1.99 \\
\hline
\end{tabular}




\section{Conclusions and future research}

Prior to the implementation of downsizing strategies, Telefónica registered lower ratios, values and profitability than after these strategies were carried out. This is largely due to the risk present in the Telefónica market, which is smaller once these strategies were implemented, since focus was placed on sectors which are more consistent with the company's management experience in its core business. As a result, the forecast profitability is greater and the value of the shares rises. Furthermore, the debt market performs a better evaluation of the company's situation, which means when operational risk is reduced conditions are more favorable to obtain funding in the form of capital injections into the core business, such as the purchase or increased stake in Cesky Telecom, $\mathrm{O} 2$ and Telecom Italia. All this boosts the creation of value for shareholders and the Telefónica market, and facilitates continuous alignment with the market, enabling the company to adapt over time.

In sum, the growth and development achieved by Telefonica over this period of just fifteen years is plain to see. However, at the same time, downsizing strategies were implemented, geared to achieving greater adaptation with the environment, including:

- The concentration of non-strategic activities at joint units, as a means of obtaining synergies and economies of scale.

- The elimination from the business portfolio of activities in the value chain which are not associated with strategic activities.

- The concentration of the Group's core business.

- The constant alignment of the company's structure with the strategies implemented.

These downscoping strategies were implemented according to clear objectives consisting of adaptation to the environment and economic upturn. Moreover, these strategies were carried out at a specific point in time and in a proactive manner, in an attempt to anticipate the changes in the environment, and were created as systemic changes affecting the entire organization, its structure, processes and personnel, altering the different organizational variables throughout the implementation of the strategies.

The results obtained point to the fact that downsizing is a strategic alternative which enables a company to better adapt to the environment, and should not only be associated with situations of decline or corporate growth.

Future research will focus on the verification of the analysis model, both longitudinally and in other sectors, in an attempt to expand the conclusions of the study and to compare the proposed model. Expanding the research database would enable us to analyze the suitability of the downsizing strategy in relation to the company's own and sectoral characteristics, by comparing the strategies implemented by Telefónica to those of Deutsche Telecom or Telecom Italia. This would enable us to ascertain whether or not the different strategies have made a difference in the creation of value.

\section{References}

Budros, A. (2002). The mean and lean firm and downsizing: Causes of involuntary and voluntary downsizing strategies. Sociological Forum, 17(2), 307-342.

Caves, R. E., \& Porter, M. E. (1976). Barriers to exit. In D. P. Qualls, \& R. T. Massons (eds.). Essays in Industrial Organization in Honor of Joe S. Bain (pp. 39-69). Cambridge, MA.: Ballinger.

Chinzer, N., \& Currie, E. (2014). Assessing longitudinal relationships between financial performance and downsizing. Management Decisions, 52(8), 1474-1490.

Conrad, J. (1989). The price effect of option introduction. Journal of Finance, 44, 487-498. 
Dahl, S. A. \& Nesheim, T. (1998). Downsizing strategies and institutional environments, Scandinavian Journal Management, 14(3), 239257.

Davis, J., Savage, G. Steward, R., \& Chapman, R. (2003). Organizational downsizing: A review of literature for planning and research/practitioner application, Journal of Healthcare Management, 48(3), 181-194.

Dewitt, R.-L. (1998). Firm, industry and strategy influences on choice of downsizing approach. Strategic Management Journal, 19(1), 59-79.

Fernández, P., \& Carabias, J. (2007). Creación de valor para los accionistas de Telefónica 1991-2006 [IESE Research Papers D/635]. IESE Business School, Navarra.

Freeman, S., \& Cameron, K. (1993). Organizational downsizing: a convergence and reorientation framework. Organization Science, 4, 10-29.

Gandolfi, F. (2007). Downsizing corporate survivors, and employability- related issues: A european case study. Journal of American Academy of Business, Cambridge, 12(1), 50-56.

Gandolfi, F., \& Hansson, M. (2011). Causes and consequences of downsizing: Towards an integrative framework. Journal of Management \& Organization, 17(4), 498-521.

Greenhalgh, L. Lawrence, A., \& Sutton, R. (1988). Determinant of workforce reduction strategies in declining organizations. Academy of Management Review, 13, 241-254.

Gresov, K. (1989). Exploring fit and misfit with multiple contingencies. Administrative Science Quarterly, 34(3), 431-456.

Hannan, M., \& Freeman, J (1984). Structural Inertia and Organizational Change. American Sociological Review, 49(2), 149-164.
Hotchkiss, E. S., \& Strickland, D. (2003). Does shareholder composition matter? Evidence from de market reaction to corporate earnings announcements. Journal of Finance, 58(4), 14891498.

Hyderabad, R. L. (2014). Corporate Restructuring. KIIT Journal of Management, 1O(1), 108-126.

Johnson, R. A. (1996). Antecedents and outcomes of corporate refocusing. Journal of Management, 22(3), 439-483.

Kotler, P. (1986). Principles of marketing. Englewood Cliffs, N. J.: Prentice Hall.

Kreiken, J. (1980). Effective vertical integration and disintegration strategies. New York: McGraw Hill, 256-263.

Littler, C. R. (1998). The dynamics of downsizing in Australia and New Zeland. Asia Pacific Journal of Human Resources, 35(1), 65-79.

López, S., \& Pueyo, A. (2002). Colaboración bajo incertidumbre: la formación de un grupo tecnológico. Economía Industrial, 346, 81-96.

Magán, A., \& Céspedes, J. (2012). Why are Spanish companies implementing Downsizing?. Review of Business, 32(2), 5-22.

Markides, C. C. (1995). Diversification, restructuring and economic performance. Strategic Management Journal, 16(2), 101-118.

McKinley, W. \& Mone, M. A. (1998). Some ideological foundations of organizational downsizing. Journal of Management Inquiry, 7(3), 198-212.

Miles, R. E. \& Snow, C.C. (1995). The new network firm: A spherical structure on a human investment philosophy. Organizational Dynamics, 23(4), 5-18.

Morris, J. R.; Cascio, W. F., \& Young, C. E. (1999, Winter). Downsizing after all these 
years: Questions and answers about who did it, how many did it and who benefited from it. Organizational Dynamics, 27(3), 78-87.

Muñoz Bullon, F., \& Sanchez-Bueno, M. (2010). Downsizing implementation and financial performance. Management Decisions, 48(8), 1181-1197.

Nadler, D. A., \& Tushman, M. I. (1998). Strategic organization design: Concepts, tools \& processes. Illinois: Scott, Foresman \& Co.

Porter, M.E. (1985). Competitive advantage. New York: Free-press.

Suarez Gonzalez, I. (2000). Downsizing: Does it really improve organizational performance? International Journal of Management, 18(3), 163-171.

Sutton, R. \& D’Aunno, T. (1989). Decreasing organizational size: Untangling the effects of money and people. Academy of Management Review, 14, 194-212.

Telefónica (2006). Accionistas e inversores: Informes anuales 1985 - 2006. España: Autor. Retrieved from https://www.telefonica.com/es/ web/shareholders-investors/

Whitney, J. O. (1996). Strategic renewal for business units. Harvard Business Review, 74(4), 84-98.

Williams, T. C., Rains, J. (2007). Linking strategy to structure: The power of systematic organization design. Organization Development Journal, 25(2), 163-171.

Worley, C. G., \& Lawler, E. (2006). Designing organizations that are built to change. MIT Sloan Management Review, 48(1), 19-23.

\section{About the authors:}

1. Carmen, Soria Bravo. PhD Economics, UNED. E-mail csoria@madrid.uned.es

2. Alfonso, Herrero de Egańa Espinosa de los Monteros, PhD Economics, UNED.

E-mail: alherrero@cee.uned.es

\section{Contribution of each author:}

\begin{tabular}{lcc}
\hline Contribution & Carmen Soria & Alfonso Herrero de Egaña \\
\hline 1. Definition of research problem & $\sqrt{ }$ & $\sqrt{ }$ \\
2. Development of hypotheses or research questions (empirical studies) & $\sqrt{ }$ & $\sqrt{ }$ \\
3. Development of theoretical propositions (theoretical Work) & & $\sqrt{ }$ \\
4. Theoretical foundation/ Literature review & & $\sqrt{ }$ \\
5. Definition of methodological procedures & $\sqrt{ }$ \\
6. Data collection & $\sqrt{ }$ \\
7. Statistical analysis & $\sqrt{ }$ \\
8. Analysis and interpretation of data & $\sqrt{ }$ \\
9. Critical revision of the manuscript & $\sqrt{ }$ \\
10. Manuscript Writing & & $\sqrt{ }$ \\
\hline
\end{tabular}

